\title{
Primary breast peripheral T-cell lymphoma not otherwise specified: report of a case
}

\author{
Daisuke Muroya $\cdot$ Uhi Toh $\cdot$ Nobutaka Iwakuma \\ Shino Nakagawa $\cdot$ Mai Mishima $\cdot$ Ryuji Takahashi $\cdot$ \\ Miki Takenaka $\cdot$ Kazuo Shirouzu $\cdot$ Yoshito Agaki
}

Received: 29 October 2012/ Accepted: 2 September 2013/Published online: 7 January 2014

(C) The Author(s) 2014. This article is published with open access at Springerlink.com

\begin{abstract}
Malignant lymphomas of the breast are rare and primary breast lymphoma comprises $<0.5 \%$ of breast malignancies, within which T-cell lymphomas are an even rarer subset. We report a case of primary breast peripheral T-cell lymphoma not otherwise specified (PTCL-NOS). Histology of the biopsied specimen revealed $\mathrm{CD} 2(+)$, $\mathrm{CD} 3(+), \mathrm{CD} 4(+), \mathrm{CD} 5(-), \mathrm{CD} 7(+), \mathrm{CD} 8(-), \mathrm{CD} 20(-)$, CD25(-), CD30(+), CD56(-), bcl-2(-), EBV-ISH(-), TIA-I(-), and ATLA negative. The patient was treated with six cycles of the CHOP regimen and died 17 months after the diagnosis was made, despite complete remission after conventional chemotherapy. To our knowledge, only 18 cases of primary peripheral T-cell lymphoma of the breast and just one previous case of primary PTCL-NOS of the breast have been reported in Japan.
\end{abstract}

Keywords Primary breast lymphoma .

Peripheral T-cell lymphoma not otherwise specified (PTCL-NOS)

\section{Introduction}

Primary breast lymphomas (PBLs) account for only $0.04-0.5 \%$ of breast malignancies. The most frequent PBLs are of the B-cell type, whereas the T-cell type is especially rare. We report a case of primary breast peripheral $\mathrm{T}$-cell lymphoma not otherwise specified

D. Muroya $\cdot$ U. Toh $(\varangle) \cdot$ N. Iwakuma $\cdot$ S. Nakagawa

M. Mishima - R. Takahashi - M. Takenaka - K. Shirouzu •

Y. Agaki

Department of Surgery, University of Kurume Faculty

of Medicine, 67 Asahi-machi, Kurume, Fukuoka, Japan

e-mail: utoh@med.kurume-u.ac.jp
(PTCL-NOS) and compare its features with those of the 17 cases of PBL reported in Japan. Low-grade lymphomas should be managed with excision biopsy and/or local radiation therapy, whereas high-grade lymphomas are generally managed with a systemic chemotherapy regimen combined with radiation therapy. Radical surgery is not recommended for breast PBL patients, as they are usually suffering from systemic disease [1-3]. This case report describes a patient with T-cell lymphoma involving the breast parenchyma.

\section{Case report}

A 77-year-old woman presented to a city hospital with the chief complaint of a painless, palpable mass in the right breast; however, the results of fine needle aspiration cytology were inconclusive. One month later, computer tomography (CT) showed bilateral pleural effusions and she was moved to our university hospital. Routine physical examination revealed a $1.5-\mathrm{cm}$ diameter, round mass in the upper outer quadrant of her right breast. A heterogenic mass was seen on ultrasonography (Fig. 1b), but nothing was seen on a diagnostic mammogram (Fig. 1a). Her medical history included a 15 -year history of hypertension, well controlled with medication. Results of a staging chest $\mathrm{X}$-ray film, a complete blood count, and liver function tests were normal, except for a high IL-2R of $1803 \mathrm{U} / \mathrm{ml}$. Magnetic resonance imaging (MRI) revealed a $2.2-\mathrm{cm}$ diameter mass in the right breast, showing a malignant imaging pattern in dynamic study, but no metastasis in the bilateral axillary lymph nodes (Fig. 2). Scintigraphy also showed increased gallium uptake in the left submandibular gland. Subsequent ultrasound-guided biopsy demonstrated atypical lymphocytes containing medium to large round 

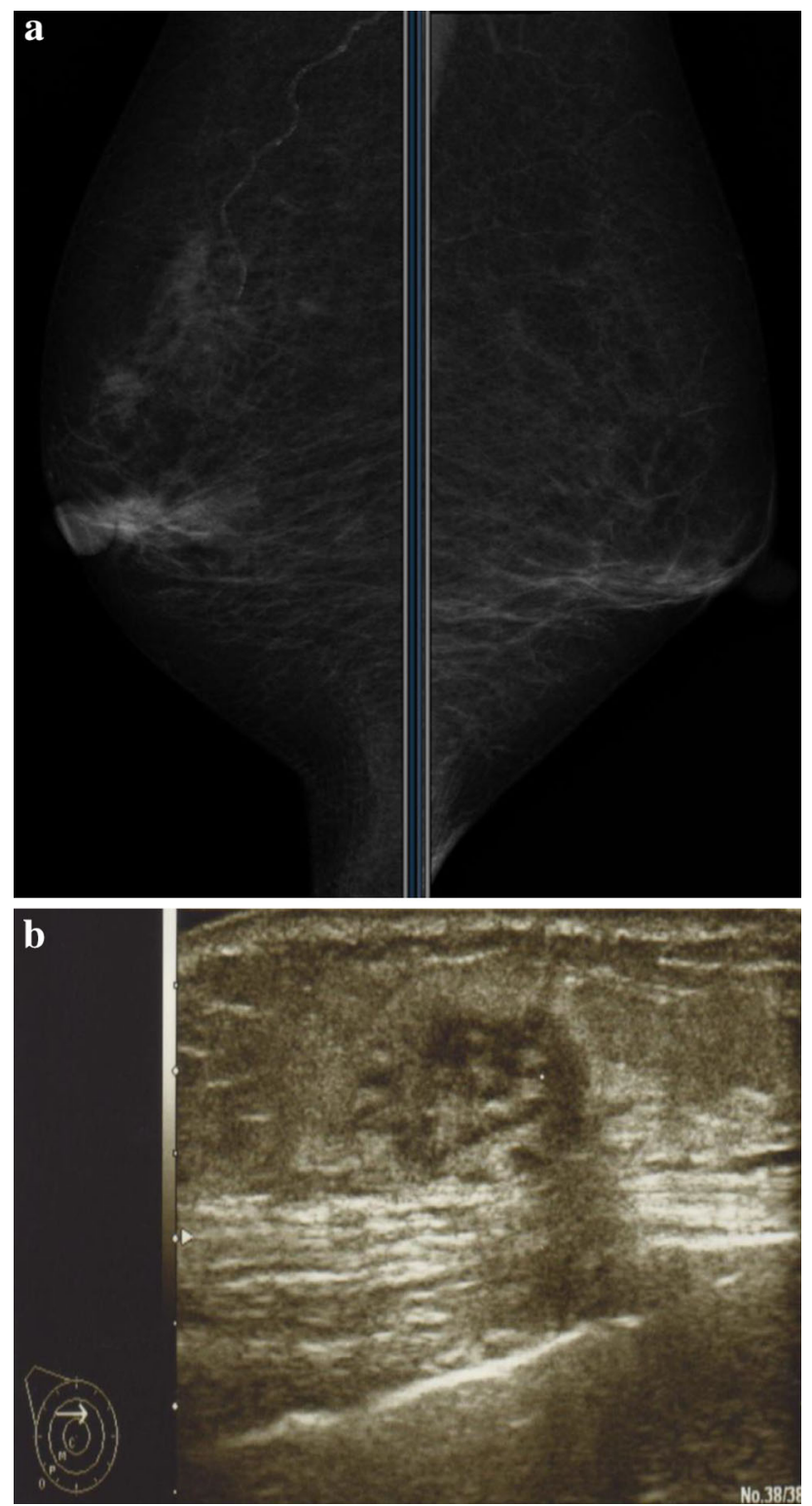

Fig. 1 a Mammogram findings. The craniocaudal and mediolateral oblique (MLO) view revealed no mass lesion or other abnormality in the bilateral breasts. b Ultrasonography findings. An irregular, round and solid hypoechoic nodule in the 11:00 o'clock position corresponds to a nodule palpated on clinical examination

nucleoli. Histologic analysis of the biopsy specimen was consistent with a peripheral T-cell lymphoma not otherwise specified and microscopic pathology revealed atypical lymphocytes containing medium to large round nucleoli and irregular nuclear shapes (Fig. 3a). Immunohistochemistry revealed $\mathrm{CD} 2(+), \mathrm{CD} 3(+)$ (Fig. 3b), $\mathrm{CD} 4(+)$, CD5(-), CD7(+), CD8(-), CD20(-) (Fig. 3c), CD25(-), CD30(+), CD56(-), bcl-2(-), EBV-ISH(-), TIA-I(-), and ATLA negative. Simultaneously, a $2.5-\mathrm{cm}$ diameter mass was found in the left mandibular area. Fine needle aspiration was performed by an otolaryngologist and

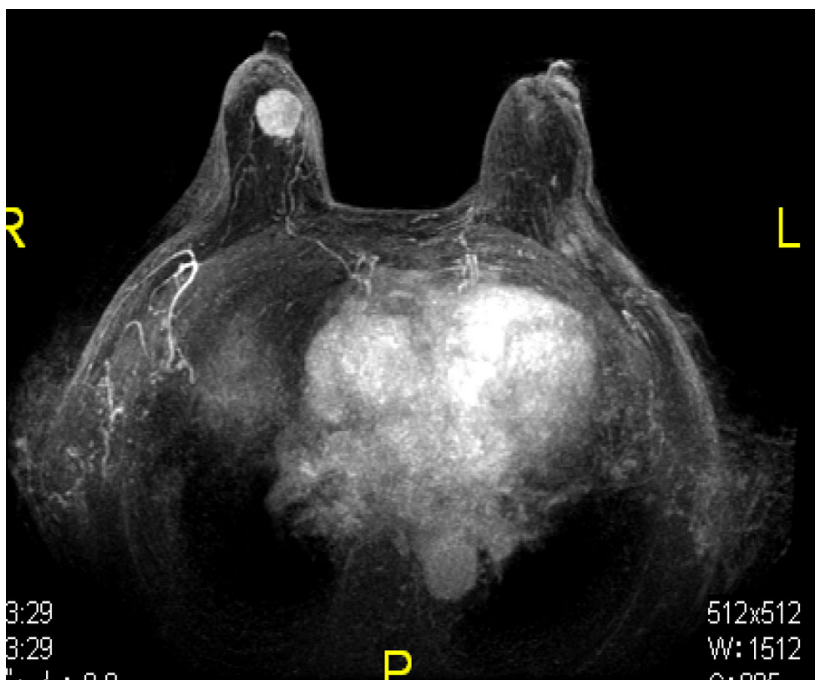

Fig. 2 Magnetic resonance imaging findings. A $3 \times 2 \times 2 \mathrm{~cm}$ mass in the upper right breast showed a malignant imaging pattern on dynamic study

cytological examination revealed a malignant lymphoma with the features of PTCL-NOS. Although there was no evidence of metastasis in specimens of bone marrow biopsy, the cytology of the pleural effusion had shown the same involvement of malignant lymphoma. Even without associated lymph node involvement, we diagnosed Stage IV PTCL-NOS with three extralymphatic organs; namely the breast, mandibular gland, and pleural effusion, prior to the chemotherapy. On re-evaluating her initial breast MRI, the CT scan had shown the breast mass progressing rapidly with a significant increase in tumor size and in the pleural effusions (Fig. 4a) before treatment.

Based on the National Comprehensive Cancer Network (NCCN) guidelines, the patient was given systemic chemotherapy using the standard CHOP regimen (cyclophosphamide: $750 \mathrm{mg} / \mathrm{m}^{2}$; doxorubicin: $50 \mathrm{mg} / \mathrm{m}^{2}$; vincristine: $1.4 \mathrm{mg} / \mathrm{m}^{2}$; prednisone: $40 \mathrm{mg} / \mathrm{m}^{2}$ ) instead of surgical treatment. Six cycles of CHOP were administered at 21-day intervals over 4 months by the hematologist as follows: cyclophosphamide, doxorubicin and vincristine were given intravenously on day 1 , with prednisone given orally $30 \mathrm{~min}$ prior to chemotherapy on day 1 , then every $24 \mathrm{~h}$ on days $2-5$.

CT scan showed a significant remission of the breast mass and pleural effusion in nearly complete response (Fig. 4b). However, the patient suffered some serious adverse effects during the chemotherapy, including grade 2 nausea, vomiting, and constipation, grade 3 neutropenia, and grade 2 heart disorder with palpitations and shortness of breath. Despite a dramatic response being achieved 6 months after beginning the CHOP therapy, it was discontinued because of heart failure, as recommended by the cardiologist. The disease relapsed in the third month after 

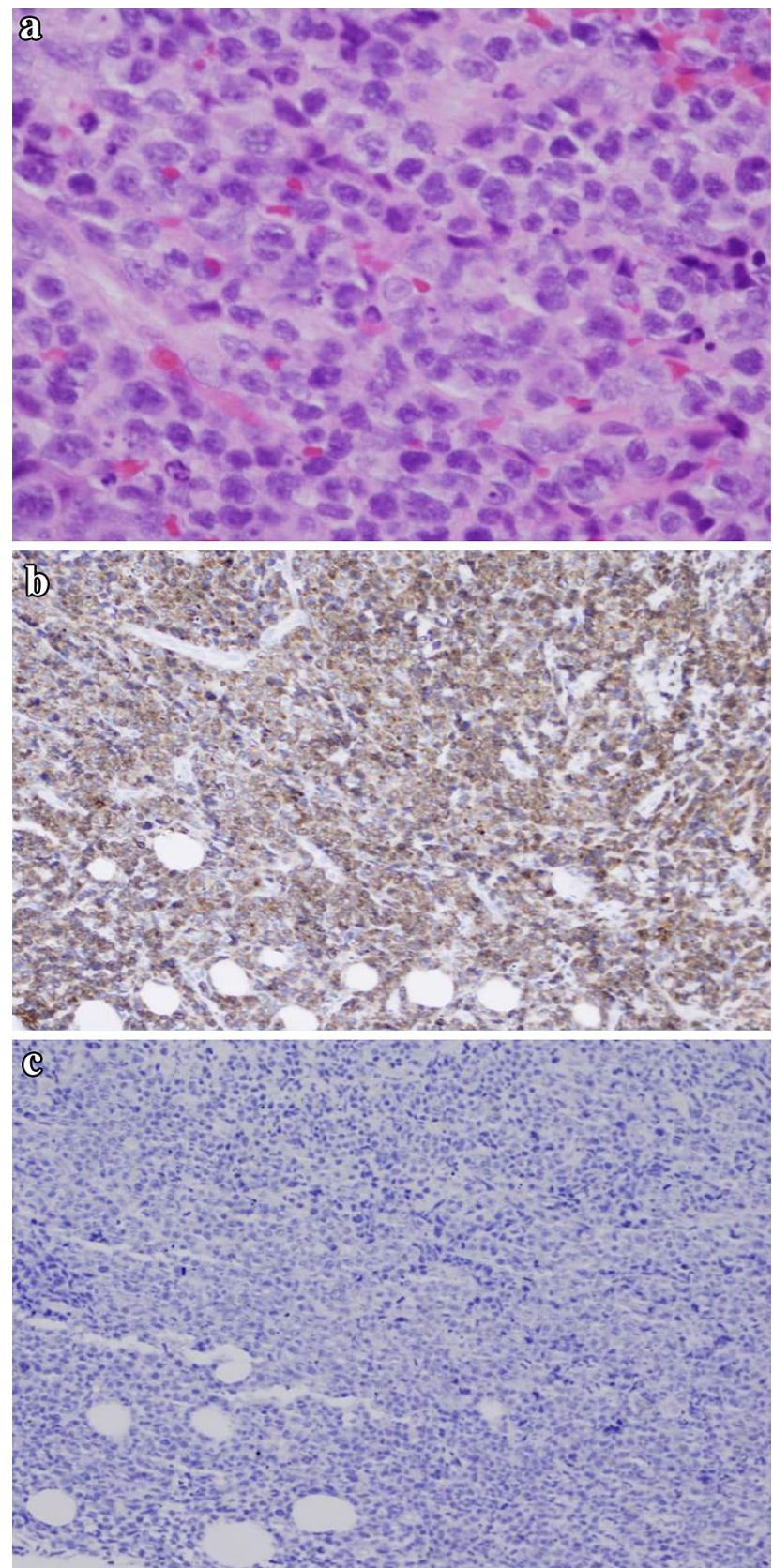

Fig. 3 a Microscopic examination revealed neoplastic infiltrates composed of medium to large cells with round nuclei (HE, original magnification $\times 400$ ). b Immunohistochemical stain of CD3 revealed a strongly positive reaction within the tumor tissue (original magnification $\times 400$ ). $\mathbf{c}$ Immunohistochemical stain of CD20 revealed a negative reaction within the tumor tissue (original magnification $\times 100)$

interrupting the CHOP, with a significant increase in the white blood cell count; however, no breast lump was detected at her last visit to the hospital. The patient did not wish to undergo any further aggressive therapy. She received palliative care until she died 17 months after the diagnosis.
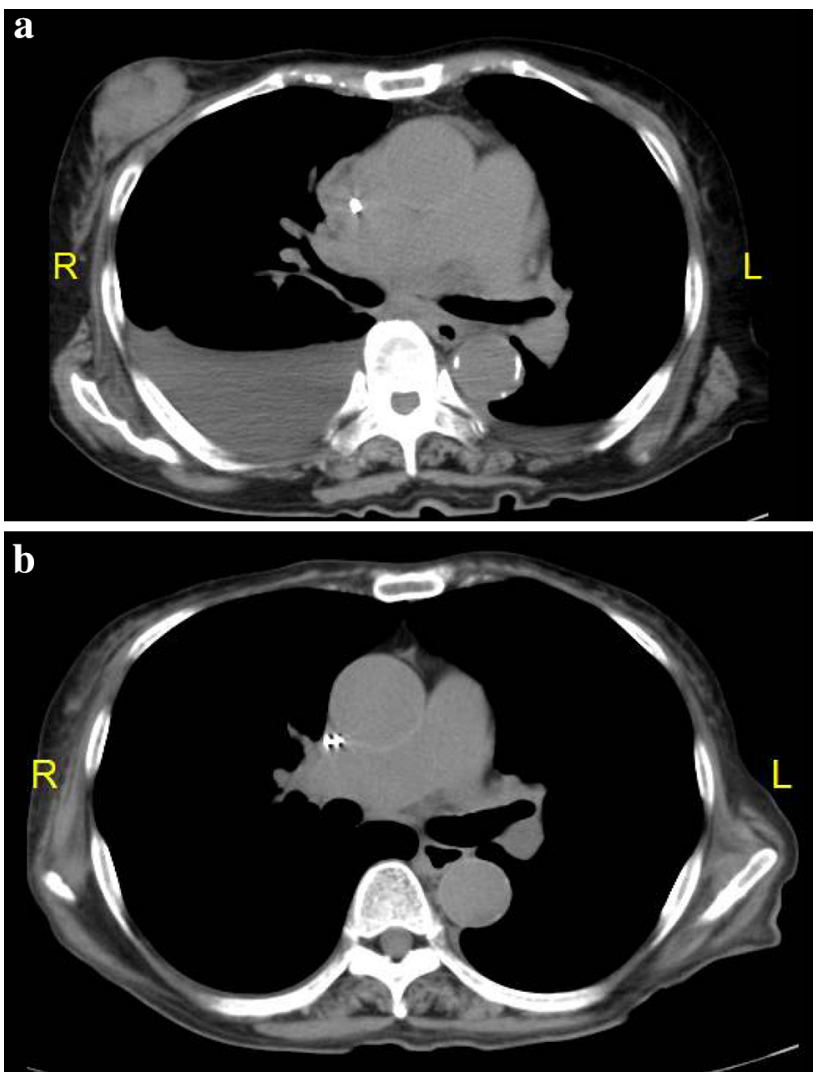

Fig. 4 a Computed tomography showed a round mass, $4.8 \times 2.6 \times 5 \mathrm{~cm}$, in the outer upper quadrant of the right breast with pleural effusions in both lungs before treatment. b The mass in the right breast and bilateral pleural effusions disappeared with nearly complete response after 6 cycles of CHOP chemotherapy

\section{Discussion}

PBL represents $0.2-1.5 \%$ of breast malignancies [4-6], while T-cell lymphomas represent $<15 \%$ of all nonHodgkin's lymphomas (NHLs) [7]. Breast T-cell lymphomas are extremely rare and reported mainly as isolated cases. In fact, we found that only 17 cases were documented in Japan between 1983 and 2010.

The typical clinical symptom is one or multiple painless masses, similar to breast B-cell lymphoma and breast carcinoma. Enlarged ipsilateral axillary lymph nodes are reported in $13-50 \%$ of PBL cases [8], although our patient did not present with this symptom. Interestingly, most cases of breast lymphoma have unexplained right side predominance, as in the present case. There are no pathognomonic mammographic features for breast lymphoma in general, and sometimes these lesions are only detected by ultrasound [9].

Although a palpable mass in the left submandibular gland was found simultaneously in our patient, the gastrointestinal tract and nasopharyngeal topography are the most frequent sites of involvement. When breast 


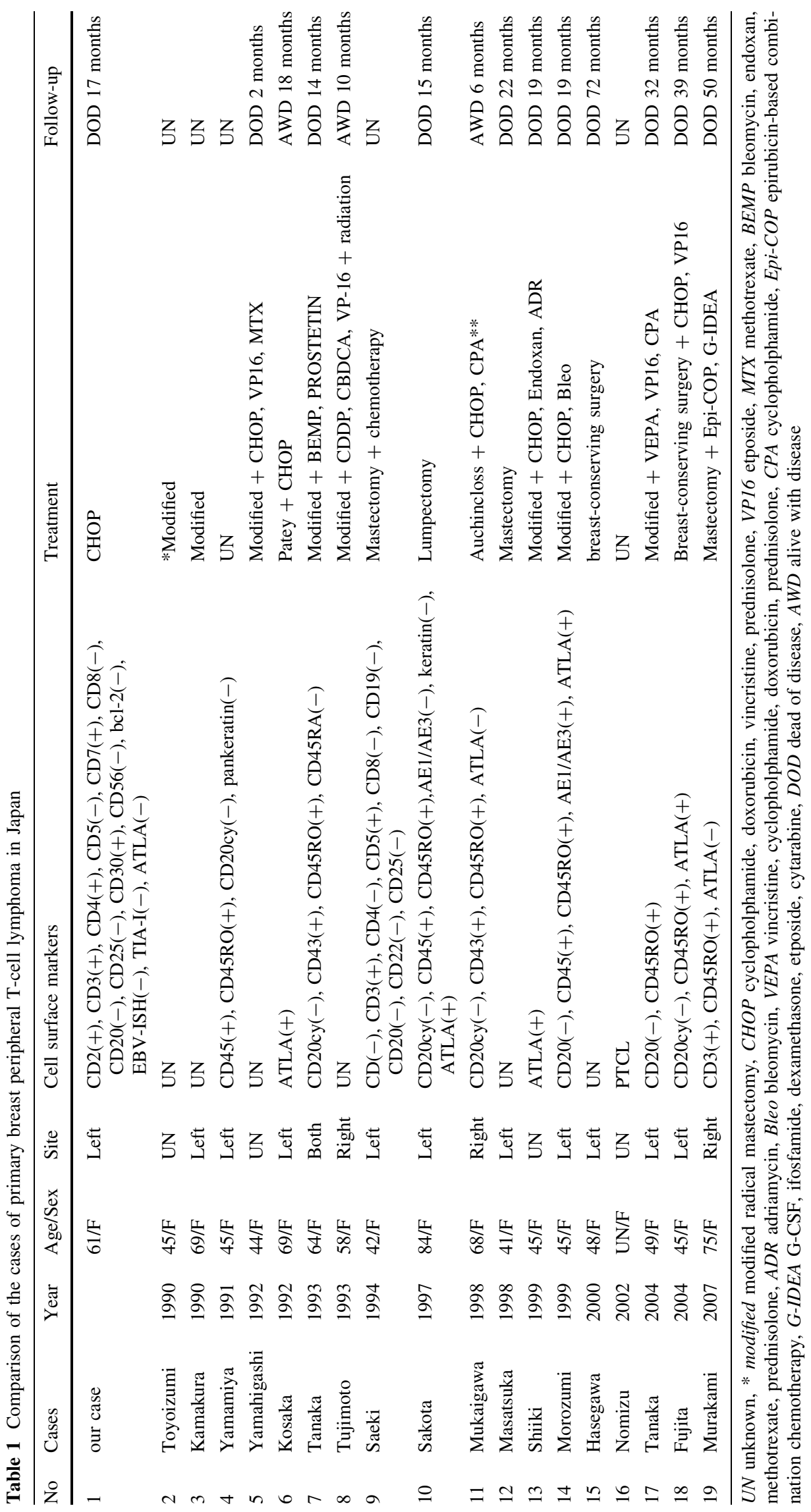


involvement is the presenting manifestation, it usually occurs in the context of other systemic disease. Involvement of the breast by precursor T-lymphoblastic lymphoma/leukemia presents as a mass or as bilateral diffuse involvement [10]. Nevertheless, the subtype of adult T-cell lymphoma/leukemia (ATLL) is most frequent in Japan, whereas PTCL-NOS is the most common type in North America and Europe, and natural killer/T-cell lymphoma (NKTCL) and ATLL are common in Asia. Moreover, several reports document cases of T-cell breast lymphoma associated with a breast implant [11-17], with anaplastic large cell lymphoma (ALCL) being the most common lymphoma found proximal to the implant [12].

The pathogenesis of T-cell lymphoma in the breast is poorly understood because of its rarity. As shown in Table 1, histopathological analysis of the 17 cases of PBL revealed 5 cases of ATLL, 1 of PTCL-NOS, and the 12 remaining cases were difficult to classify or reclassify according to the criteria proposed by the World Health Organization classification of tumors of hematopoietic and lymphoid tissue. PTCL-NOSs are mainly nodal lymphomas, accounting for more than $50 \%$ of all T-cell lymphomas in adults, whereas the present case was exceptionally unusual in that it was an extranodal, extracutaneous T-cell lymphoma with a well-defined mass, occurring in a setting of leukemic disease. To the best of our knowledge, this represents only the second case of primary PTCL-NOS of the breast in Japan. From several years ago, scientific societies have proposed guidelines to standardize therapeutic strategies. The NCCN offers different solutions based on histology and clinical stage according to the Ann Arbor Classification [1, 18, 19]. Resective biopsy and conservative surgery is sufficient for pathologic evaluation. In fact, the role of surgery for PBL should be limited to assisting in establishing a definitive diagnosis [1]. Our patient received only systemic chemotherapy without surgical resection, unlike in other reported cases. Little is documented about the progress of primary T-cell lymphoma of breast, and the clinical outcome of these patients is variable although most had an aggressive disease course. Uesato et al. [20] found that tumor diameter and lymphomatous dissemination to the axillary lymph nodes was associated with a poor prognosis, with only $10 \%$ (1/10) 5-year overall survival (OS). In contrast, PTCL-NOS is usually aggressive and relapses are common [21-24]. Both clinical stage and the international prognostic index (IPI) score used for other non-Hodgkin lymphomas (NHLs) have demonstrated the correlation of the overall survival of these patients [25]. Patients with PTCL generally have a worse prognosis than patients with $\mathrm{B}$ cell NHL [21]. Accordingly, our patient also suffered relapse and survived for only 17 months after her diagnosis. New strategies for refractory PBL are warranted.
Regarding the clinical approaches to primary peripheral T-cell lymphoma of the breast, women presenting with a breast mass should undergo a fine needle aspiration (FNA) or core needle biopsy (CNB). Moreover, women with abnormal imaging findings alone, such as abnormal calcification, should undergo biopsy guided by mammography, ultrasound, or breast MRI. Primary breast lymphoma, including PTCL-NOS, is a heterogeneous category and essentially a diagnosis of exclusion. In fact, the diagnostic agreement rate among expert pathologists is only about $75 \%$ [26]. Although FNA is useful for distinguishing reactive B cell hyperplasias from clonal mature B cell neoplasms as an initial screening test [27-29], only an excisional biopsy of an intact node consistently obtains sufficient tissue for histologic, immunologic, molecular biologic assessment, and classification by experienced pathologists [30]. An accurate diagnosis of lymphoma based on FNA is not possible [31], which is probably why our patient came to our hospital without a definitive diagnosis.

In conclusion, we believe that patients with breast disease should undergo not only FNA, but also image-guided core biopsies to provide sufficient tissue for diagnosis. Complete evaluation, using an adequate tissue sample for accurate diagnosis, is most important to predict prognosis and design treatment for patients with primary peripheral T-cell lymphoma of the breast, including PTCL-NOS.

Acknowledgments We thank Professor Kouichi Ohshima for his outstanding advice and pathologic technical assistance.

Conflict of interest The authors have no conflict of interest.

Open Access This article is distributed under the terms of the Creative Commons Attribution License which permits any use, distribution, and reproduction in any medium, provided the original author(s) and the source are credited.

\section{References}

1. Avenia N, Sanguinetti A, Cirocchi R, Bistoni G, Trastulli S, D'Ajello F, et al. Primary breast lymphomas: a multicentric experience. World J Surg Oncol. 2010;8:53.

2. Jennings WC, Baker RS, Murray SS, Howard CA, Parker DE, Peabody LF, et al. Primary breast lymphoma: the role of mastectomy and the importance of lymph node status. Ann Surg. 2007;245:784-9.

3. Jeanneret-Sozzi W, Taghian A, Epelbaum R, Poortmans P, Zwahlen D, Amsler B, et al. Primary breast lymphoma: patient profile, outcome and prognostic factors. A multicentre Rare Cancer Network study. BMC Cancer. 2008;8:86.

4. Arber DA, Simpson JF, Weiss LM, Rappaport H. Non-Hodgkin's lymphoma involving the breast. Am J Surg Pathol. 1994;18: 288-95.

5. Wiseman C, Liao KT. Primary lymphoma of the breast. Cancer. 1972;29:1705-12.

6. Saito H, Takahashi F, Yamamoto H, Nanasawa T, Ohtani H, Tsuda H. Bilateral malignant lymphoma of the breast in patients 
with a familial history of cancer: a report of three cases. Surg Today. 1994;24:737-40.

7. Jaffe E, Harris N, Stein H. Introduction on overview of the classification of the lymphoid neoplasms. In: Swerdlow SH, Campo E, Harris NL, Jaffe ES, Pileri SA, Stein H, et al., editors. World Health Organization classification of tumours. Pathology and genetics of tumours of haematopoietic and lymphoid tissues. Lyon: IARC Press; 2008. p. 158-66.

8. Talwalkar SS, Miranda RN, Valbuena JR, Routbort MJ, Martin AW, Medeiros LJ. Lymphomas involving the breast: a study of 106 cases comparing localized and disseminated neoplasms. Am J Surg Pathol. 2008;32:1299-309.

9. Sabaté JM, Gómez A, Torrubia S, Camins A, Roson N, De Las Heras P, et al. Lymphoma of the breast: clinical and radiologic features with pathologic correlation in 28 patients. Breast $\mathbf{J}$. 2002;8:294-304.

10. Arber DA, Simpson JF, Weiss LM, Rappaport H. Non-Hodgkin's lymphoma involving the breast. Am J Surg Pathol. 1994;18:288-95.

11. Gaudet G, Friedberg JW, Weng A, Pinkus GS, Freedman AS. Breast lymphoma associated with breast implants: two casereports and a review of the literature. Leuk Lymphoma. 2002;43:115-9.

12. Sahoo S, Rosen PP, Feddersen RM, Viswanatha DS, Clark DA, Chadburn A. Anaplastic large cell lymphoma arising in a silicone breast implant capsule: a case report and review of the literature. Arch Pathol Lab Med. 2003;127:115-8.

13. Roden AC, Macon WR, Keeney GL, Myers JL, Feldman AL, Dogan A. Seroma-associated primary anaplastic large-cell lymphoma adjacent to breast implants: an indolent T-cell lymphoproliferative disorder. Mod Pathol. 2008;21:455-63.

14. Newman MK, Zemmel NJ, Bandak AZ, Kaplan BJ. Primary breast lymphoma in a patient with silicone breast implants: a case report and review of the literature. J Plast Reconstr Aesthet Surg. 2008;61:822-5.

15. Fritzsche FR, Pahl S, Petersen I, Burkhardt M, Dankof A, Dietel $\mathrm{M}$, et al. Anaplastic large-cell non- Hodgkin's lymphoma of the breast in periprosthetic localisation 32 years after treatment for primary breast cancer-a case report. Virchows Arch. 2006;449:561-4.

16. Keech JA Jr, Creech BJ. Anaplastic T-cell lymphoma in proximity to a saline-filled breast implant. Plast Reconstr Surg. 1997;100:554-5.

17. Vasei M, Kumar PV, Malekhosseini SA, Amirghofran Z. Primary T-cell lymphoma of the breast with lymphoepithelial lesion. A case report. APMIS. 1997;105:445-8.

18. Carbone PP, Kaplan HS, Mushoff K, Smithers DW, Tubiana M. Report of the committee on Hodgkin's disease classification. Cancer Res. 1971;31:1860-1.
19. National Comprehensive Cancer Network: (http://www.nccn.org/ index.asp).

20. Uesato M, Miyazawa Y, Gunji Y, Ochiai T. Primary nonHodgkin's lymphoma of the breast: report of a case with special reference to 380 cases in the Japanese literature. Breast Cancer. 2005; $12: 154-8$.

21. Weisenburger DD, Linder J, Armitage JO. Peripheral T-cell lymphoma: a clinicopathologic study of 42 cases. Hematol Oncol. 1987;5:175.

22. Coiffier B, Brousse N, Peuchmaur M, Berger F, Gisselbrecht C, Bryon PA, et al. Peripheral T-cell lymphomas have a worse prognosis than B-cell lymphomas: a prospective study of 361 immunophenotyped patients treated with the LNH- 84 regimen. The GELA (Groupe d'Etude des Lymphomes Aggressives). Ann Oncol. 1990;1:45.

23. Armitage JO, Greer JP, Levine AM, Weisenburger DD, Formenti $\mathrm{SC}$, Bast $\mathrm{M}$, et al. Peripheral T-cell lymphoma. Cancer. 1989;63:158.

24. Lippman SM, Miller TP, Spier CM, Slymen DJ, Grogan TM. The prognostic significance of the immunotype in diffuse large-cell lymphoma: a comparative study of the T-cell and B-cell phenotype. Blood. 1988;72:436.

25. Schmitz N, Trümper L, Ziepert $M$, Nickelsen $M$, Ho AD, Metzner B, et al. Treatment and prognosis of mature T-cell and NK-cell lymphoma: an analysis of patients with T-cell lymphoma treated in studies of the German High-Grade Non-Hodgkin Lymphoma Study Group. Blood. 2010;116:3418.

26. Weisenburger DD, Savage KJ, Haris NL, Gascoyne RD, Jaffe ES, MacLennan KA, et al. Peripheral T-cell lymphoma, not otherwise specified: a report of 340 cases from the International Peripheral T-cell Lymphoma Project. Blood. 2011;117:3402.

27. Steinfort DP, Conron M, Tsui A, Pasricha SR, Renwick WE, Antippa P, Irving LB. Endobronchial ultrasound-guided transbronchial needle aspiration for the evaluation of suspected lymphoma. J Thorac Oncol. 2010;5:804.

28. Florentine BD, Staymates B, Rabadi M, Barstis J, Black A. The reliability of fine-needle aspiration biopsy as the initial diagnostic procedure for palpable masses: a 4-year experience of 730 patients from a community hospital-based outpatient aspiration biopsy clinic. Cancer. 2006;107:406.

29. Hehn ST, Grogan TM, Miller TP. Utility of fine-needle aspiration as a diagnostic technique in lymphoma. J Clin Oncol. 2004;22:3046.

30. Swerdlow SH, Campo E, Harris NL, Jaffe ES, Pileri SA, Stein H, et al., editors. World Health Organization classification of tumours of haematopoietic and lymphoid tissues. Lyon: IARC Press; 2008.

31. Armitage JO, How I. Treat patients with diffuse large B-cell lymphoma. Blood. 2007;110:29. 